\title{
CYTOLOGICAL ANALYSIS OF ULTRAVIOLET IRRADIATED ESCHERICHIA COLI
}

\author{
II. Ultraviolet Induction of Lysogenic E. COli ${ }^{1}$
}

JOHN I. PAYNE, PHILIP E. HARTMAN, ${ }^{2}$ STUART MUDD, AND CHARLOTTE LIU

Department of Microbiology, School of Medicine, University of Pennsylvania, Philadelphia 4, Pennsylvania

Received for publication March 21, 1955

The majority of an Escherichia coli strain K12 population hereditarily carries the potential to produce lambda phages following an appropriate stimulus. Effective inducing agents for phage production for this organism are ultraviolet radiation (Weigle and Delbrück, 1951) with a sharp peak in the spectrum at $265 \mathrm{~m} \mu$ (Franklin, 1954), X-rays (Yanofsky, 1953; Marcovitch, cited in Lwoff, 1953), gamma rays (Marcovitch, cited in Lwoff, 1953), methyl-bis-( $\beta$-chloroethyl)amine (Jacob, 1952) and azaserine (Gots et al., 1955). Ultraviolet and methyl-bis-( $\beta$-chloroethyl)amine have an identical effect on the cytology of K12 induction (Kellenberger, 1953).

The site of the prophage in the bacterial cell has been postulated as a specific locus on the bacterial chromosome (Lederberg, 1951; Lederberg and Lederberg, 1953; Appleyard, 1953, 1954a, 1954b; Wollman, 1953; Fredericq, 1953). Experiments involving superinfection with mutants (Jacob and Wollman, 1953) are consistent with a mean prophage number per cell equal to the mean number of bacterial nuclei (close to three) in these haploid (Lederberg et al., 1951) cells. Derivatives of K12 ("immune" strains) have been obtained which exhibit certain properties of, and respond to induction like lysogenic K12 but produce almost no phage (Appleyard, 1954b; Wollman, 1953).

The current report describes the comparative cytology of induced K12, two K12 immune strains, and infection with exogenous lambda phages. Also included are cytological investigations of certain nutritional conditions found by Gots and Hunt (1953) to affect lambda matura-

${ }^{1}$ This work has been aided by a grant from the United States Atomic Energy Commission, AEC Contract no. AT(30-1)-1342.

${ }^{2}$ Present address: Department of Bacteriology and Immunology, Harvard Medical School, Boston 15, Massachusetts. tion. Methods are as described in Hartman et al. (1955).

\section{RESULTS}

Maturation of lambda in induced K12. Cells grown on salt-glucose medium are competent and produce phage on both broth and synthetic media following induction with ultraviolet radiation. The change undergone by the nuclear material of individual cells on each medium is described below. These changes are not so striking and progress more slowly in synthetic medium, presumably because of the general nutritional limitation imposed on all growth processes. The cytological observations agree with information obtained by biological assay.

When cells are grown on broth medium prior to irradiation, nutritional conditions profoundly affect lambda maturation. Phage production in broth will first be described. The latent period in broth was $75 \mathrm{~min}$, the rise period lasted 15 to 20 min, and the burst size varied from 100 to 250 . The per cent induction ranged from 69 to 100 and the remaining viable (colony-forming) cells were generally less than 1 per cent. The difference between the total of the plaque-forming cells plus viable cells and the number of cells present was listed as cells inactivated by irradiation. This population showed the greatest fluctuation, ranging from 0 to 31 per cent. The number of viable cells remained constant for over $1 \frac{1}{2}$ hours. Excluding occasional minor increases due to effects of manipulation there is a constant number of plaque-forming units during the latent period; this indicates a lack of cell division also by the induced cells of the population. Single cell burst experiments showed each induced cell to produce a normal burst. As in the other studies, controls carried out with each series of slides defined the nature of the cell population in each experiment, forming the basis for cytological interpretation. 


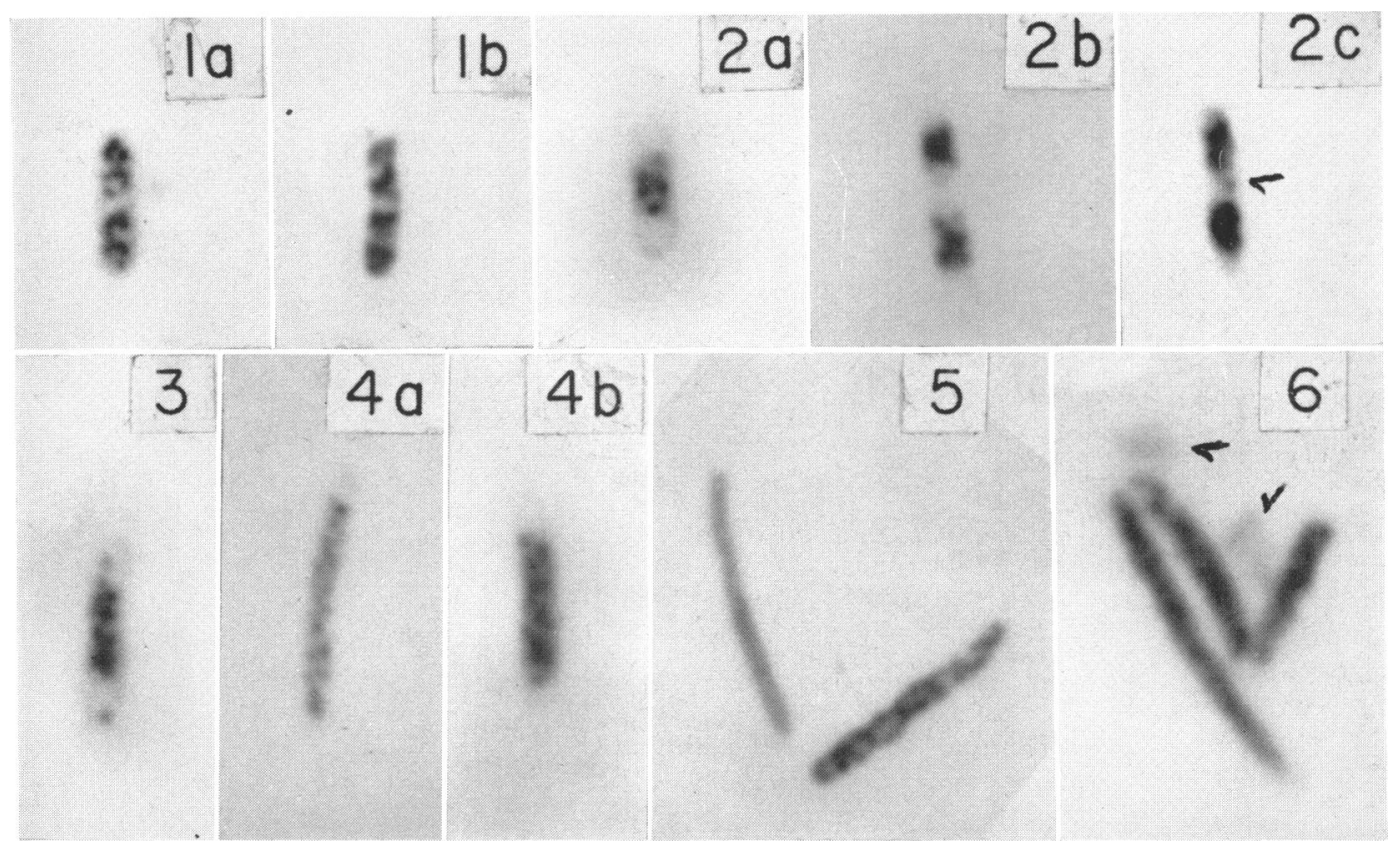

Figures $1-6$. Effect of ultraviolet radiation on $E$. coli K12 (lambda lysogenic). All figures reproduced here at a final magnification of $3,675 \times$. Preparations are as described in the previous report. In all cases, 40 sec. irradiation was used. Times denote min. incubation in broth post-UV. 1: Log phase nonirradiated cells of K12. (a) Azure A stain. (b) May Greenwald-Giemsa. 2: 15 min. (a-b) Azure A. (c) May Greenwald-Giemsa. 3: $30 \mathrm{~min}$. (a) Azure A. 4: $45 \mathrm{~min}$. (a) Azure A. (b) May Greenwald-Giemsa. 5: $60 \mathrm{~min}$. Azure A. 6:75 min. Azure A.

The cytological changes occurring in the $\mathrm{K} 12$ cells during the first 30 min (figure $2(\mathrm{a}-\mathrm{c})=15$ min post-irradiation; figure $3=30 \mathrm{~min}$ postirradiation) were exactly as those seen in the nonlysogenic K12S, i.e., aggregation of the contracted chromosomes and the flowing together of adjacent nuclei, central nuclear masses whose components were unresolved by the light microscope, polar and peripheral basophilic, ribonucleasesensitive granules, and cell elongation. Perinuclear ribonuclease-resistant granules were also present (arrow, figure 2c). However, at 30 minutes, when evidence of chromosomal fragmentation just began to appear in a few cells of $\mathrm{K} 12 \mathrm{~S}$, many of the K12 chromosomes had broken down to smaller units. These structures decreased in size and increased in number by $40 \mathrm{~min}$ and showed further increase in number by $50 \mathrm{~min}$, at which time they began moving toward the poles of the elongating cells (figures $4(\mathrm{a}-\mathrm{b})=45 \mathrm{~min}$ ). By $60 \mathrm{~min}$ (figure 5) some cells were quite dense with chromatin. In some cases, the chromatinic granules extended throughout the cell to the poles which, until then, had remained clear of this material. The increase in cell size until this time had been primarily due to elongation, but now some cells increased in width. Elongation practically ceased after $60 \mathrm{~min}$ and all cells were wider after $70 \mathrm{~min}$, many dense with chromatinic material. At $80 \mathrm{~min}$ there remained a few intact cells which were filled with chromatinic material. Some cells at this time showed signs of release of their chromatin by eruption of material from the polar region, although this may have been an effect of the fixation (figure $6=75$ min post-irradiation). At 90 min post-irradiation, the few cells present were granular and dense or, in rare instances, contained an axial filament of chromatin. Lightly stained distorted masses were present in many preparations. Very rarely a normal-looking cell was seen; these probably represented the survivors of the ultraviolet treatment.

In several experiments in which the per cent induction was low (near 70 per cent) and the number of presumably dead cells (non-plaque or colony formers) was high (near 30 per cent), the killed cells underwent the same nuclear changes 


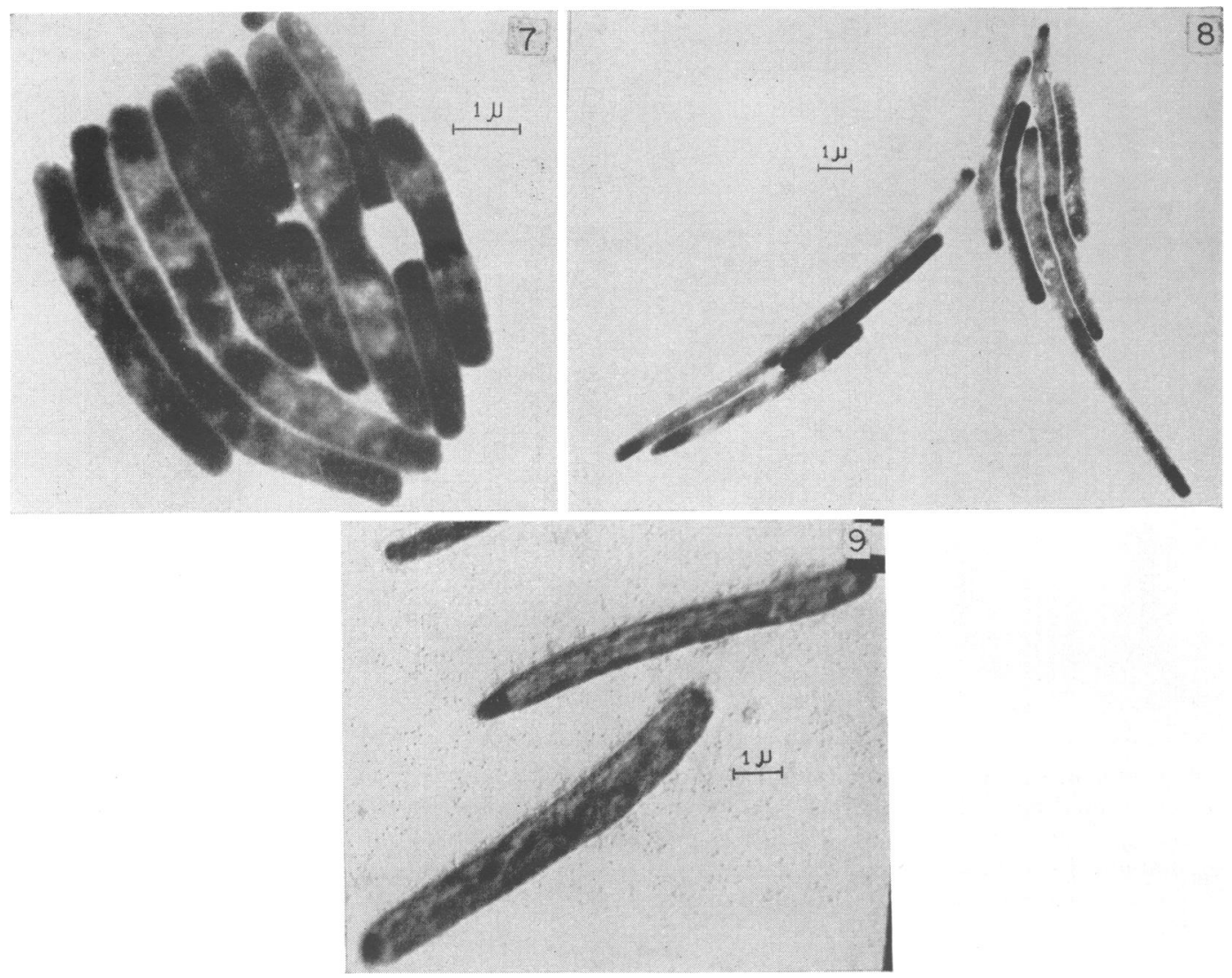

Figures 7-9. Electron micrographs. 7: K-12: 30 min. after 40-sec. ultraviolet irradiation. Fusion of the light nuclear areas to form a centralized area. 8: K-12: 75 min. after 40-sec. ult raviolet irradiation, showing elongation of cells and electron transparency along the cell length. 9: K-12: 2 hr. after 40-sec. ultraviolet irradiation, showing extracellular, induced lambda phage and intracellular granules in cells. Figure 7 was unshadowed; figures 8 and 9 were lightly shadowed with chromium.

The authors are indebted to Mr. Delbert Philpott of the Marine Biological Laboratory, Woods Hole, Mass., for the electron micrographs presented as figures 7 and 8. An RCA EMU-2B model electron microscope was used. We are indebted to Dr. Warren R. Stinebring, Department of Microbiology, School of Medicine, University of Pennsylvania, for figure 9, which was taken on the Philips Electron Microscope in the Department of Pathology, University of Pennsylvania.

as the phage-producing cells and, further, the majority of them lysed at the same time as other cells in the culture. The only difference we have been able to detect in these two classes of cells is the inability of one group, the killed cells, to form plaques (i. e., the release of infective lambda).

The same alterations followed in the light microscope by nuclear staining techniques could be detected in cells in the electron microscope. The light nuclear areas of normal cells were fused and centralized and the cells more granular at $30 \mathrm{~min}$ after irradiation (figure 7 ). By $75 \mathrm{~min}$ the cells had elongated considerably and were electron transparent along most of their length (figure 8). No intracellular phage particles could be discerned with certainty, but following cell lysis they could be discerned on the collodion membrane (figure 9). Gorrill and Challice (1955) have demonstrated collapsed spheres, presumably derived from the cell walls of lysed cells (Mudd et al., 1953), in electron pictures of lysogenic K12 following ultraviolet induction.

Lambda maturation on synthetic medium. Lambda maturation in broth-grown cells transferred to synthetic medium after ultraviolet 
irradiation was investigated by light microscopy only. Broth-containing agar plates were used for assays, since lambda does not form visible plaques on salt-glucose agar with $\mathrm{K} 12 \mathrm{~S}$ as indicator. Viable cells after irradiation varied from 3 to 12 per cent, and 74 to 85 per cent of these cells formed plaques. The latent period varied from 90 to $120 \mathrm{~min}$ and the rise period was prolonged (90 to 180 min after induction). The burst was low (2 to 20); single cell burst analyses showed the number of lambda particles released from individual cells to vary from 0 to 19 .

Almost all cells of the culture underwent the cytological changes previously described for maturation in complex medium, although the changes occurred more slowly and there was no great elongation of the cells or increase of deoxyribonucleic acid. A small proportion of the cells did not lyse but remained as at the nuclear fusion stage of development.

The cysteine effect of Gots and Hunt. With the addition of $100 \mu \mathrm{g}$ per $\mathrm{ml}$ of cysteine to saltglucose medium used for lambda maturation of broth-grown cells, there was a progressive decrease in the number of recoverable infectious centers. This is in agreement with the report of Gots and Hunt (1953). The cysteine inhibition was not 100 per cent, for a small burst appeared between 90 and 120 minutes, at which time less than 0.5 per cent of the cells released lambda. Cysteine did not alter the initial percentage of induction but inactivated the potentially infectious centers shortly after ultraviolet irradiation. The number of $\mathrm{K} 12$ survivors was also decreased.

Cytological preparations showed cysteine to inhibit the initial, nuclear fusion stage of the ultraviolet effect. The complete fusion of the nuclei did not occur before $90 \mathrm{~min}$ or later in the majority of cells. A few cells went through the characteristic changes at the same time intervals as those found in salt-glucose populations and these were interpreted as the phage-producing portion of the culture. The chromatin of the aborting cells became more granular and was distributed along the non-elongated cells in an irregular fashion $2 \mathrm{hr}$ after irradiation. The cells remained in this state for at least an additional $2 \mathrm{hr}$.

Effects of ultraviolet on K12 "immune" strains. $\mathrm{K} 12$-i1 and K12-i2 were grown in broth, and given the same treatment as the $\mathrm{K} 12$ cells. $\mathrm{Al}$ - though survival was approximately that of $\mathrm{K} 12$, no lambda phage was detected from K12-i1 after induction treatment although the tests would have detected one infective particle released per $2 \times 10^{6}$ cells. K12-i2 released about one particle for every $3 \times 10^{5}$ cells irradiated.

Nuclear stains revealed changes in the nuclei and cytoplasm analogous to those described for lysogenic $\mathrm{K} 12$ on broth medium, including an increment in chromatinic material late in the latent period. In addition, mass lysis of the cultures took place at the same time. Examination of immune cells in the electron microscope revealed no apparent differences in morphological developments leading to lysis from those taking place in lysogenic K12. No phage particles or phage-like particles could be identified consistently in the debris from either immune strain.

Responses to exogenous lambda phages. Log phase cultures of cells of non-lysogenic K12S were exposed to a multiplicity of 1 to 10 exogenous lambda phages, adsorption was allowed to occur for 10 minutes, and anti-lambda rabbit immune serum added to inactivate the free phage. Our log phase cultures at $37 \mathrm{C}$ adsorbed lambda very poorly; however, the cultural conditions were maintained to avoid the small cell size and presence of heterogeneity in nuclear structure found in saturated cultures, transformations due to temperature alterations (Klieneberger-Nobel, 1947), etc.

There was no detectable cytological or biological response in the cells due to the addition of any of the lambda phages in most of the population. These are interpreted as refractory cells which have not adsorbed phage. At the multiplicities used no killing other than through lysis was detected. No nuclear change could be directly related to lysogenization. Therefore, of the various responses of sensitive cells to lambda phages (Lieb, 1953a, 1953b) only the lytic cycle was cytologically examined in detail.

The temperate lambda produced, after a 45 min latent period, a lytic response in a small per cent of cells of log phase broth cultures. The responses to lambda $\mathrm{c}$ and lambda $\mathrm{v}$ were identical with that of lambda ${ }^{+}$. Cytological preparations revealed a small per cent of cells whose nuclear elements were somewhat condensed at $15 \mathrm{~min}$ and disrupted and broken down into granules by $20 \mathrm{~min}$. These cells were partially filled with coarsely granular chromatin by $30 \mathrm{~min}$. The 
chromatin was more finely granular and the cells contained more chromatin by $45 \mathrm{~min}$. Some of the cells containing coarse granules persisted after the rise period was completed. It is possible that these cells underwent lysis several hours later (as found in growth experiments by Rita, 1953).

\section{DISCUSSION}

In confirmation of Kellenberger (1953), it was found that the early changes undergone by the lysogenic cells in response to ultraviolet irradiation are identical cytologically to those of the cells of the non-lysogenic derivative (Hartman et al., 1955). Therefore, during the first half of the latent period the changes noted in the induced cells are considered to be in response to the ultraviolet stimulus. Indeed, fundamentally the same changes are found in a number of $E$. coli strains (Kellenberger, 1952), including strain $\mathrm{B}$ and its Furacin- and radiation-resistant derivatives (to be published). Only during the last half of the latent period do changes in the cytology influenced by vegetative phage multiplication and maturation occur. Comparable lambdalysogenic and non-lysogenic derivatives of $E$. coli strain C show the same general effects as the K12 derivatives (Hartman and Payne, unpublished), in spite of the unique nuclear configurations found in this strain (Kellenberger, 1953), and the host-induced modifications of the phage progeny (Bertani and Weigle, 1953; Weigle and Bertani, 1953).

Fine granulation of chromatin and increase thereof in the latter stages of the latent period is found in cells exogenously infected with lambda phages in which lysis will take place. In $\mathrm{K} 12$, $\mathrm{K} 12-\mathrm{i} 1$, and $\mathrm{K} 12-\mathrm{i} 2$ an increment in chromatinic material per cell also appeared late in the latent period; this was true also of cells which produced phage after infection with exogenous phages. The "immune" strains, however, produced no phage or phage-like particles after treatment that could be detected consistently with the electron microscope.

Jacob and Wollman (1953), in discussion of their data on the induction of phage development in lysogenic bacteria, conclude:

"The hypothesis of a bacterial disturbance, either spontaneous or induced, as the primary cause of phage development is therefore the only one to be considered ...., the effect of the pri- mary bacterial disturbance is graduated and inhomogeneously distributed inside the bacterium, the development of prophage being only a secondary event."

Lwoff (1953) considers that in induction "certain bacterial properties are modified, e. g., the synthesis of a nucleic acid. The development of the prophage is a secondary event, the probability of which is governed by the metabolic state reached by the bacterium."

Several amino acids are required for lambda maturation of broth-grown cells (Gots and Hunt, 1953). An apparent relationship exists between this requirement and the types of amino acids necessary to decrease the lag period imposed on the growth of broth-grown cells when transferred to synthetic media (Gots and Hunt, personal communication). Cytologically, lambda maturation on synthetic medium progresses as though general nutritional limitations were imposed upon its development. Unlike the experiments of Borek (1952), in which specific growth requirements of auxotrophic derivatives were omitted from the medium, the process of lambda maturation here does progress at a slow rate. Cysteine when present without threonine is unique in inciting an actual abortion of infectious centers (Gots and Hunt, 1953). In the presence of cysteine a very long delay is found in the initial stages of nuclear fusion after ultraviolet. Although this may at first appear to be a qualitative difference in amino acid effect from that discussed above, this difference could prove to be merely quantitative. In support of the latter interpretation, Joklik (1953) has reported cysteine to prolong the lag period of $E$. coli cells in synthetic medium.

\section{SUMMARY}

The effects of ultraviolet irradiation on lysogenic strains (K12, K12-i1, and K12-i2) of Escherichia coli have been studied. The cytological effects can be divided into two phases. The initial effects (first phase) are like those found also in non-lysogenic cells (Hartman et al., 1955). The latter phase, involving fine granulation of chromatin, increase in chromatin, and cell lysis, is found also in cells lytically infected with exogenous lambda $a^{+}$, lambda c or lambda $\mathrm{v}$ phages. In exogenous infection, the initial phase is greatly shortened or does not appear.

The present and preceding article describe a characteristic sequence of cytological changes, 
produced by ultraviolet radiation and other injurious agents, which deviate markedly from the usual pattern of reduplication and distribution of nuclear chromatin. We suggest the hypothesis that these aberrations in distribution of genetic determiners may bear some causal relationship to such genetic phenomena as induction, mutation and certain aspects of recombination and segregation.

\section{ADDENDUM}

When these papers were in press, a further report by Kellenberger (1955) appeared on the effects of $\mathrm{x}$-radiation on cytological sequences in $E$. coli. Kellenberger concludes: "The hypothesis, that the fragmentation of nucleoids may be directly related to induction of lysogenic cells, is postulated."

\section{REFERENCES}

APpleyard, R. K. 1953 Segregation of lambda lysogenicity during bacterial recombination in E. coli K-12. Cold Spring Harbor Symposia Quant. Biol., 18, 95-97.

APPLEYARD, R. K. 1954a Segregation of lambda lysogenicity during bacterial recombination in Escherichia coli K-12. Genetics, 39, 429-439.

Appleyard, R. K. $1954 b$ Segregation of new lysogenic types during growth of a doubly lysogenic strain derived from Escherichia coli K12. Genetics, 39, 440-452.

Bertani, G., and Weigle, J. J. 1953 Host controlled variation in bacterial viruses. $\mathbf{J}$. Bacteriol., 65, 113-121.

BorEK, E. 1952 Factors controlling aptitude and phage development in a lysogenic Escherichia coli K-12. Biochim. et Biophys. Acta, 8, 211-215.

Franklin, R. 1954 The action spectrum for the ultraviolet induction of lysis in Escherichia coli K-12. Biochim. et Biophys. Acta, 13, 137138.

FredericQ， P. 1953 Transfert génétique des propriétés lysogènes chez $E$. coli. Compt. Rend. Soc. Biol., 147, 2046-2048.

Gorrill, R. H., and Challice, C. E. 1955 Further observations on the electron microscope changes following induction of $E$. coli K12. Biochim. et Biophys. Acta, 16, 82-86.

Gots, J. S., .. ND Hunt, G. R., JR. 1953 Amino acid requirements for the maturation of bacteriophage in lysogenic Escherichia coli. J. Bacteriol., 66, 353-361.

Gots, J. S., Bird, T. J., ANd Mudd, S. 1955 L-Azaserine as an inducing agent for the development of phage in the lysogenic Esche- richia coli, K-12. Biochim. et Biophys. Acta' 17, 449-450.

Hartman, P. E., Payne, J. I., and Mudd, S. 1955 Cytological analysis of ultraviolet irradiated Escherichia coli. I. Cytology of lysogenic $E$. coli and a non-lysogenic derivative. J. Bacteriol., 70, 531-539.

$\mathrm{J}_{\mathrm{ACOB}}$, F. 1952 Production de bactériophages par action de la methyl bis-(chloroethyl) amine sur des bactéries lysogènes. Compt. Rend. Acad. Sci., 234, 2238-2240.

$\mathrm{J}_{\mathrm{ACOB}}, \mathrm{F}$., AND Wollman, E. L. 1953 Induction of phage development in lysogenic bacteria. Cold Spring Harbor Symposia Quant. Biol., 18, 101-121.

JокLIK, W. K. 1953 The effect of cysteine on phage multiplication and growth of Bacterium coli. Riassunti delle Cumunicazioni, VI Intern. Congr. Microbiol., Rome, Italy, II 201-202.

KELLENBERGER, E. 1952 Les transformations des nucléoïdes de $E$. coli provoquées par les rayons ultraviolets. Experientia, 8, 263.

Kellenberger, E. 1953 Les formes caracteristiques des nucléoïdes de $E$. coli et leurs transformations dues à l'action d'agents mutagenes-inducteurs et de bactériophages. 6th Intern. Congr. Microbiol., Rome, Italy, Rend. ist. super sanità, Suppl., 45-66.

Kellenberger, E. 1955 Les transformations des nucléoides de Escherichia coli déclenchées par les rayons X. Experientia, 11, 305-307.

KLieneberger-Nobel, E. 1947 Morphological appearances of various stages in $B$. proteus and coli. J. Hyg., 45, 410-412.

LEDERBERG, E. M. 1951 Lysogenicity in E. coli K-12. Genetics, 36, 560 .

Lederberg, E. M., and Lederberg, J. 1953 Genetic studies of lysogenicity in $E$. coli. Genetics, 38, 51-64.

LederberG, J., Lederberg, E. M., Zinder, N. D., ANd Lively, E. R. 1951 Recombination analysis of bacterial heredity. Cold Spring Harbor Symposia Quant. Biol., 16, 413-443.

LieB, M. 1953a The establishment of lysogenicity in Escherichia coli. J. Bacteriol., $65,642-651$.

Lieb, M. $1953 b$ Studies on lysogenization in Escherichia coli. Cold Spring Harbor Symposia Quant. Biol., 18, 71-73.

Lworf, A. 1953 Lysogeny. Bacteriol. Revs., 17, 269-337.

Mudd, S., Hillier, J., Beutner, E. H., and Hartman, P. E. 1953 Light and electron microscopic studies of Escherichia colicoliphage interactions. II. The electron microscopic cytology of the $E$. coli B-T2 
system. Biochim. et Biophys. Acta, 10, 153179.

Rita, G. 1953 Alcune osservazioni sul processo di lisogenizzazione di Escherichia coli. Riassunti delle Comunicazioni, VI Intern. Congr. Microbiol., Rome, Italy, II, 217-218.

Weigle, J. J., ANd Bertani, G. 1953 Variations des bactériophages conditionnées par les bactéries hôtes. Ann. inst. Pasteur, 84, 175-179.
Weigle, J. J., And Delbrǘck, M. 1951 Mutual exclusion between an infecting phage and a carried phage. J. Bacteriol., 62, 301-318.

Wollman, E. L. 1953 Sur le determinisme génétique de la lysogénie. Ann. inst. Pasteur, 84, 281-293.

YANOFSKY, C. 1953 Effects of $x$-rays on the formation of lactase in a lysogenic strain and a sensitive strain of Escherichia coli. J. Bacteriol., 65, 383-387. 